\title{
Dual Role Conflict and Social Support on the Performance of Women Entrepreneurs with Disabilities During the Covid-19 Pandemic (An Initial Research)
}

\author{
Penny Handayani ${ }^{1}$, Benedicta Evienia ${ }^{2}$, Sri Hapsari Wijayanti ${ }^{3}$, Regina Widyani ${ }^{4}$, Frenicha ${ }^{5}$ \\ ${ }^{1}$ Psychology, UNIKA Atma Jaya, Indonesia ${ }^{2}$ \\ Management, UNIKA Atma Jaya, Indonesia ${ }^{3}$ \\ Accountancy, UNIKA Atma Jaya, Indonesia ${ }^{4}$ \\ Psychology, UNIKA Atma Jaya, Indonesia \\ Management, UNIKA Atma Jaya, Indonesia ${ }^{5}$ \\ ${ }^{1}$ E-mail address: penny.handayani@ atmajaya.ac.id; ${ }^{2}$ E-mail address: benedicta.ep@atmajaya.ac.id \\ ${ }^{3}$ E- mail address : sri.hapsari@atmajaya.ac.id \\ Indonesia
}

\section{ABSTRACT}

During the COVID-19 pandemic, many female entrepreneurs are trying to maintain their household financial cycles from the businesses they own. Therefore, they need social support from their family and environment to maintain the business performance that they had built before the COVID-19 pandemic. This research is the initial research of a large umbrella of research with the topic of Analysis of the Effect of Multiple Role Conflicts on Performance Women Entrepreneurs During the COVID-19 Pandemic with Social Support as Moderating Variable. This study examines the picture of dual role conflict and social support on the performance of women entrepreneurs with disabilities during the Covid-19 pandemic. The outputs are expected to help women entrepreneurs with disabilities maintain their business performance by reducing dual role conflicts and getting social support from the surrounding environment. Data collection was carried out with a qualitative approach with snowball sampling which was taken through interviews with six selected respondents. The characteristics of the sample are: 1) Female: married and (was) married, has at least 1 child, 2) Have a business/entrepreneurship for at least the last 6 months, 3) People with hearing disabilities, and 4) Domiciled on the island of Java. Based on the results of the study, the effect of multiple roles on the performance of women entrepreneurs was slightly felt in families with children aged over 12 years, while housewives who had children under 12 years had a considerable influence. The performance of women entrepreneurs during the Covid-19 pandemic has increased, this is due to declining economic conditions. While forms of social support that help women entrepreneurs to maintain their performance as entrepreneurs during the Covid-19 pandemic are instrumental support, informational support, emotional support, and positive assessments obtained from family and friends. Social support is the main thing for women entrepreneurs to overcome dual role conflicts in their families, the social support they get comes from the family so that dual role conflicts in the family do not occur in women entrepreneurs.

\section{Keywords: women, disability, entrepreneurs, pandemic Covid-19}

\section{INTRODUCTION}

Indonesia is one of the countries in Asia that has the potential in developing women's entrepreneurs. Data shows that women's participation in the business sector has increased from time to time. Data in 2012 shows the involvement of women in the field of entrepreneurship as much as 58 percent. In 2018, Bank Indonesia stated that the total Micro, Small, and Medium Enterprises (MSMEs) reached 57.83 million with more than $60 \%$ managed by women (the number of female MSME actors in Indonesia reached 37 million). The entrepreneurial sector has been recognized as an important factor supporting the stability of developing countries (Ratten, 2014). Information from katadata.co.id, Micro, Small, and Medium Enterprises (MSMEs) have proven to be the driving force for economic growth in Indonesia. This can be seen from the high contribution of MSMEs to gross domestic product (GDP) which reached 60 percent in 2018. Women's participation in MSMEs contributes up to 9.1 percent of GDP, and about 5 percent of exports.

As individuals, women face many problems when building and managing their businesses. These barriers are influenced by multiple roles in the family, education level, lack of training, lack of self-confidence, lack of funds, legal and social formalities (Sunita,2013). With their limitations, women need to empower themselves and others through community empowerment by forming businesses for social change and increasing economic activity. 


\author{
E-ISSN: 2469-6501 \\ VOL: 7, ISSUE: 11 \\ November/2021 \\ DOI: http://dx.doi.org/10.33642/ijbass.v7n11p3 \\ (c) $)$ \\ https://creativecommons.org/licenses/by/4.0/
}

Many studies have shown that high levels of workplace conflict can be associated with the emergence of negative stress and psychological well-being. Many women complain about negative pressure because of the various conflicts they experience. In addition to having multiple role conflicts, women also often lack adequate social support. In fact, in various studies, social support provided to entrepreneurs has an important role in the entrepreneurial process. In several studies, it has been shown that parental support and environmental support play an important role for a person to cultivate entrepreneurial interest (Indarti, N. \& Rostiani, R. 2008; Lee, L., Wong, PK, Foo, M. Der, K. \& Leung, A. 2011). During the COVID-19 pandemic, many women entrepreneurs are trying to maintain their household financial cycles from the businesses they own. Therefore, they need social support from their family and environment to maintain the business performance that they had built before the COVID-19 pandemic.

There is research that has been done by Rahaning (2015) that there is a difference between ideal conditions and reality. Effendi (in Irwanto, 2003) revealed that one of the reasons not many people with disabilities are working is because the company knows the potential of people with disabilities. Thinking that people with disabilities when working will become a burden for the company because they have to add operational matters, and people with disabilities do not have work skills. These things are considered by companies to employ people with disabilities and make people with disabilities hesitate to work (Rahaning, 2015). This is what ultimately chooses opening their own business to become an entrepreneur is a more open choice for women with disabilities.

With the previous explanation above, the researcher arranges research questions that will be answered through this research:

1. How does conflict affect women entrepreneurs with disabilities on the performance of women entrepreneurs in running their businesses during the COVID-19 Pandemic?

2. What forms of social support can help women entrepreneurs with disabilities to maintain their performance as entrepreneurs during the COVID-19 Pandemic?

3. How can the dynamics between family conflict and social support help women entrepreneurs with disabilities maintain their business performance during the COVID-19 Pandemic?

4. How does the role of social support help in reducing the occurrence of dual role conflicts for women entrepreneurs with disabilities?

\section{LITERATURE REVIEW}

\section{Dual Role Conflict}

According to Lee and Choo (2001), work-family conflict is divided into three parts:
1. Job-Spouse Conflict/JSC (Job-Spouse Conflict) is a conflict between female entrepreneurs who have raised a family. Women face contradictions as female workers with their role as spouses (wives).

2. Job-Parent Conflict (JPC) is a conflict faced by women about their roles as working women and mothers.

3. Job-Home Maker Conflict/JHMC (Job-Housewife Conflict) is a conflict over female entrepreneurs who have raised families because of the different roles of working women and women's roles as household administrators.

If it is based on Lee and Choo's (2001) theory, workpartner conflict, namely carrying out the role of a woman who works and becomes a wife, there is very little conflict among female entrepreneurs. This is because to meet the economic needs they support each other, not only the husband who is the main breadwinner but the wife as a partner contributes so those female entrepreneurs who have partners do not experience dual role conflicts. Women in their development are now starting to move slowly (evolutionary) inspired by the view of gender equality, housewives no longer want to be said to have no job but now dare to develop their abilities and earn their income. As the view expressed by Soedjatmoko, (in Alfons OL et al, 2017) that self-awareness and the level of emancipation of Indonesian women have increased greatly, Indonesian women do not want themselves to be only a burden to their husbands, but they want to be fighters with the same abilities and rights as their husbands. who can carry out their functions and obligations are not limited to only the responsibility of the husband. Not only that, Othman (in Ramadhani Ninin, 2016) states that the role of women has changed over the decades in helping themselves and their loved ones in achieving mutual prosperity and improving their socioeconomic status as a way to escape poverty and vulnerability.

\section{Performance of Woman Entrepreneurs}

According to As'ad (2004: 46) performance is defined as a person's success in carrying out a job. Performance components include individual capabilities, business expansion, and organizational support. Individual abilities include talents, interests, personality factors. Business includes motivation, work ethic, attendance, and task design. Meanwhile, organizational support consists of training and development, equipment and technology, management, and co-workers. The definition of performance above is the notion of performance according to Mathis (2006). Another opinion says that performance is the output produced by the functions or indicators of a job or a profession within a certain time (Wirawan, 2009:5).

In carrying out business activities, MSMEs have characteristics (Bank Indonesia Survey 2005 in Srihadiastuti, 2018), including a) human resources with a relatively low level of education, b) product quality is not standardized, c) simple technology, d) limited marketing scope in the local market, and 


\title{
International Journal of Business and Applied Social Science (IJBASS)
}

\author{
E-ISSN: 2469-6501 \\ VOL: 7, ISSUE: 11 \\ November/2021 \\ DOI: http://dx.doi.org/10.33642/ijbass.v7n11p3

e) limited capital. According to Simamora (1995), HR performance is influenced by three factors, namely: 1) Individual factors consisting of abilities and expertise, background, and demographics; 2) Psychological factors consisting of perceptions of attitude, personality, learning, and motivation; 3) Organizational factors consisting of resources, leadership, rewards, structure and job design.

\section{Social Support}

Sarason et al (1987) define social support as the intensity of the entrepreneur's interactions with friends and family to whom they feel attached. Social support can also be defined as the availability of support from friends, partners, subordinates, family, and other important people from work tools (Kariv, 2008). We can also understand social support as a social infrastructure created by trust, cooperation, and collective action that provides tangible (money, labor, distribution networks, equipment) or intangible (information, advice, moral and psychological support) resources (Kuada, 2009; Kariv, 2008).

Classification of social support, according to Sheridan and Radmacher (2009), Sarafino (2011), Taylor (2012), and House (2004); divides social support into four forms, namely:

1. Instrumental support (tangible or instrumental support).

This form of support is the provision of support in the form of material, providing opportunities and opportunities.

2. Informational support.

This form of support involves support in the form of information, advice, and instructions given to increase one's knowledge in finding solutions to solutions. This type of information can help individuals identify and resolve problems more easily.

3. Emotional support (emotional support).

This form of support involves a sense of empathy, comfort, trust that comes from social support so that individuals can deal with problems better. This support is very important in dealing with situations that are considered uncontrollable in solving problems.

4. Positive rating.

Giving awards, feedback on results or achievements, and positive criticism.

\section{Disabilities}

Disability is a condition where an individual experiences a limitation of himself which includes physical, mental, cognitive, sensory, and emotional limitations that can be caused by various factors such as poor nutrition, poor health care, to forms of violence or accidents that may have been experienced (Adioetomo,2010). Mont, \& Irwanto,2014). According to the World Health Organization (WHO) (in Oentari, 2019) states that disability is a condition of not being able to carry out certain activities like normal individuals, this is caused by conditions of loss or inability both psychologically, physiologically, or structurally, or functionally anatomical.
The definition of disability itself can vary based on various views such as religious, social, and medical. Based on religious and cultural views, disability is considered as a disability resulting from punishment for major sins that have been committed. according to

Law, Indonesia established the definition of disability in Law no. 8 of 2016 article 1 states that disability is any person who experiences physical, intellectual, mental, and sensory limitations in the long term who is interacting with the environment can experience obstacles and difficulties to participate fully and effectively with other citizens based on equality of human right.

According to the medical view, disability is a condition of a person who has a disturbed or abnormal body system that results in physical limitations in the individual. Then according to the social view, disability is a person's reaction to their limitations, these limitations include psychological and biological. With various definitions that have been stated, disability can be concluded as a condition of a person who has physical, intellectual, and mental limitations that make it difficult for the individual to interact with other people.

Disability is divided into several types based on the limitations they have. Individuals with hearing loss are referred to as deaf, loss of body/physical limbs is called tunadaksa, loss of speech function is called speech impairment, mental retardation, and loss of function. Vision, namely blind (KBBI, p. 1563). Each of these types of limitations has its challenges and obstacles. Disability is not only related to health problems but also relates to the physical condition of the body and the social environment in which the individual lives, causing a person with a disability to experience limitations in contributing to society, especially in working and earning a decent living (Adeline, Handayani, \& Irwanto, 2015).

\section{METHODOLOGY}

\section{Research Types and Methods}

This study examines the picture of dual role conflict and social support on the performance of women entrepreneurs with disabilities during the Covid-19 pandemic. The following research questions: 1) How does conflict affect women entrepreneurs with disabilities on the performance of women entrepreneurs in running their businesses during the COVID19 Pandemic? 2) What forms of social support can help women entrepreneurs with disabilities maintain their performance as entrepreneurs during the COVID-19 Pandemic? 3) How can the dynamics between family conflict and social support help women entrepreneurs with disabilities maintain their business performance during the COVID-19 Pandemic? and 4) How does the role of social support help in reducing the occurrence of dual role conflicts for women entrepreneurs with disabilities? The outputs that will be generated from this research are expected to help women entrepreneurs with disabilities maintain their business 


\author{
E-ISSN: 2469-6501 \\ VOL: 7, ISSUE: 11 \\ November/2021 \\ DOI: http://dx.doi.org/10.33642/ijbass.v7n11p3 \\ (c) (†) \\ https://creativecommons.org/licenses/by/4.0/
}

performance by reducing dual role conflicts and getting social support from the surrounding environment.

The factors that will be the focus of this research are limited to the following variables:

1. Work-Family Conflict, which includes: a) Job-Spouse Conflict, b) Job-Parent Conflict, and c) Job- Home Maker Conflict.

2. Factors Affecting the Performance of Women Entrepreneurs include a) Individual factors consisting of abilities and expertise, background, and demographics; b) Psychological factors consisting of perceptions of attitude, personality, learning, and motivation; c) Organizational factors consisting of resources, leadership, rewards, structure and job design.

3. Social support includes a) Tangible or instrumental support, b) Informational support, c) Emotional support, and) Positive assessment.

In summary, all of them can be illustrated in the research model in Figure 1

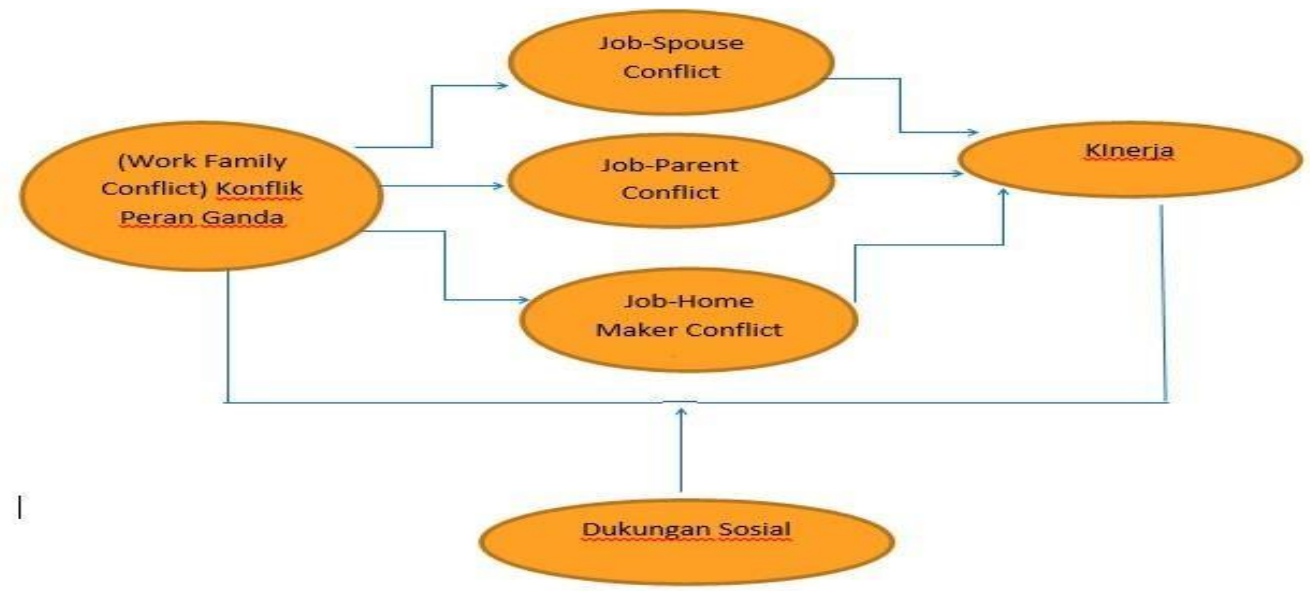

Figure 1. Research models

Data collection was carried out with a qualitative approach which was taken through interviews with six selected respondents. The sampling method used is snowball sampling, where the researcher asks the acquaintance to introduce the researcher to their relatives and friends who meet the predetermined criteria for the participants.

\section{Participant Criteria}

The characteristics of the sample selected by the researcher are:

1. Female: have been and have been married, at least the last 6 months, have at least 1 child.

2. Have a business/entrepreneurship for at least the last 6 months.

3. People with hearing disabilities.

4. Domiciled at Java Island.

\section{Method of Data Analyst}

The research used open-ended questions to get answers about work, family conflicts, the form of social support they need and get as women with disabilities. Open-ended questions also allowed the researchers to find out how they managed and maintained their social enterprise when faced with family conflict. The analysis used is thematic analysis, according to the theory used (Yin, 2016).

The writing method used is the descriptive method. Nazir (1988) states that the descriptive method is a method of examining the status of a group of people, objects, conditions, systems of thought, or a class of events in the present. The purpose of this descriptive research is to make a systematic, factual, and accurate description, picture, or painting of the facts, characteristics, and relationships between the phenomena being investigated. Following the research objective, which is to describe the dual role and social support on the performance of women entrepreneurs with disabilities during the Covid-19 pandemic, the unit of analysis of this research is individual because the researcher wants to explore in detail to answer the research objectives.

The researcher used the thematic analysis data analysis method. Thematic analysis is a method for recognizing and managing patterns in the content and meaning of qualitative data (Willig, 2013). This analytical method is used so that researchers can identify and regulate patterns in the description of dual role conflict and social support on the performance of women entrepreneurs with disabilities during the Covid-19 pandemic by the objectives of the study. The researcher coded the verbatim results of each participant to see the patterns contained in the interview answers. Then perform intraindividual and inter-individual analysis so that the research objectives can be answered in detail but also see the big picture.

\section{Research Instruments}

The research instruments used in this study were informed consent, video call applications, audio-visual recording devices, and interview guides.

Table 1. Grid of interview guide instruments in this study: 
International Journal of Business and Applied Social Science (IJBASS)

E-ISSN: 2469-6501

VOL: 7, ISSUE: 11

November/202 1

DOI: http://dx.doi.org/10.33642/ijbass.v7n11p3

(c) (i)

https://creativecommons.org/licenses/by/4.0/

Table 1: Instrument Grid

\begin{tabular}{ccll}
\hline No & \multicolumn{1}{c}{ Variabel } & \multicolumn{1}{c}{ Indikator } & \multicolumn{1}{c}{ Referensi } \\
\hline 1 & Konflik Peran Ganda & Job Spouse Conflict & (Lee and Coo, 2001 \\
& & Job Parent Conflict & \\
& & Job Home Maker Conflict & \\
2 & Dukungan Sosial & Emosional & (House, 2004) \\
& & Penghargaan & \\
& & Instrumental & (Simamora, 1995) \\
& & Informatif & \\
& \multirow{2}{*}{ Kinerja } & Faktor Individu & \\
& & Faktor Psikologis & \\
& & Faktor Organisasi &
\end{tabular}

\section{RESULT AND DISCUSSION}

Table 2. Summary of Participant Dynamics

\begin{tabular}{|c|c|c|c|c|c|c|}
\hline Aspect & Participant 1 & Participant 2 & Participant 3 & Participant 4 & Participant 5 & Participant 6 \\
\hline Name & Dewi & Nana & Dwi & Karsi & Retno & Endah \\
\hline Age & 37 years old & 44 years old & 42 years old & 48 years old & -- & 51 years old \\
\hline Education & - & - & - & $\begin{array}{l}\text { Graduated from } \\
\text { SMPLB }\end{array}$ & S1 Law & - \\
\hline Type of Disability & Deaf & Deaf & Deaf & Deaf & Deaf & Deaf \\
\hline Marital status & $\begin{array}{l}\text { Divorced } \\
\text { widow }\end{array}$ & Marry & Marry & $\begin{array}{l}\text { Divorced } \\
\text { Widow }\end{array}$ & Marry & Marry \\
\hline Number of household members & $\begin{array}{l}3 \text { people; Child } \\
\text { (2) and Dewi }\end{array}$ & $\begin{array}{l}3 \text { people; } 1 \text { child, } \\
\text { husband and Nana }\end{array}$ & $\begin{array}{l}5 \text { people; } 3 \text { children, } \\
\text { husband, and Dwi }\end{array}$ & 1 person; Karsi & $\begin{array}{l}5 \text { people; Childre } n(3) \text {, } \\
\text { husband, Retno }\end{array}$ & $\begin{array}{l}4 \text { people; Children (2), Husband, } \\
\text { Endah }\end{array}$ \\
\hline $\begin{array}{l}\text { Number of household members who } \\
\text { work/have income }\end{array}$ & 1 (Dewi) & $\begin{array}{l}2 \text { (Nana and her } \\
\text { husband) }\end{array}$ & $\begin{array}{l}2 \text { (Dwi and her } \\
\text { husband) }\end{array}$ & 1 (Ibu Karsi) & $\begin{array}{l}3 \text { (Retno, her husband } \\
\text { and first son) }\end{array}$ & 2 (Endah and her husband) \\
\hline Live with & $\begin{array}{l}2 \text { children, agirl in } 4 \text { th } \\
\text { grade and a boy in } \\
\text { kindergarten }\end{array}$ & $\begin{array}{l}\text { Husband and } \\
1 \text { child aged } 16 \\
\text { years }\end{array}$ & $\begin{array}{l}\text { Husband and } 3 \\
\text { children; 1st grade } 3 \\
\text { junior high school child, } \\
\text { 2nd grade } 1 \text { junior high } \\
\text { school child, 3rd grade } 5 \\
\text { elementary school child }\end{array}$ & Self & $\begin{array}{l}\text { Husband and } 2 \text { children. } \\
\text { I 'm the } 1 \text { st kid in Jakarta }\end{array}$ & $\begin{array}{l}\text { Husband and } 2 \text { sons, aged } 17 \text { and } \\
13 \text { years. }\end{array}$ \\
\hline Main work before COVID & $\begin{array}{l}\text { Selling clothes, masks } \\
\text { and food }\end{array}$ & $\begin{array}{l}\text { Telang flower drink } \\
\text { business }\end{array}$ & - & $\begin{array}{l}\text { Laundry } \\
\text { Workers }\end{array}$ & $\begin{array}{l}\text { Selling and making Snack } \\
\text { Boxes and Rice Boxes }\end{array}$ & $\begin{array}{l}\text { Cooking class for tourists, stalls, } \\
\text { yogurt businesses }\end{array}$ \\
\hline Main Job during COVID & $\begin{array}{l}\text { Selling clothes, masks } \\
\text { and food }\end{array}$ & $\begin{array}{l}\text { Telang flower drink } \\
\text { business }\end{array}$ & $\begin{array}{l}\text { Sewing business and } \\
\text { selling masks }\end{array}$ & $\begin{array}{l}\text { Laundry } \\
\text { Workers }\end{array}$ & $\begin{array}{l}\text { Selling and making Snack } \\
\text { Box }\end{array}$ & $\begin{array}{l}\text { Penjualan youghurt through orders } \\
\text { and dazed smoked catfish }\end{array}$ \\
\hline Side job before COVID & $\begin{array}{l}\text { Helping activities at } \\
\text { Gerkatin Sleman }\end{array}$ & - & $\begin{array}{l}\text { Helping my husband } \\
\text { sell a grocery store }\end{array}$ & - & - & Coffee shop \\
\hline Side job during COVID & $\begin{array}{l}\text { Helping activities at } \\
\text { Gerkatin Sleman }\end{array}$ & $\begin{array}{l}\text { Participate in the } \\
\text { activities of the } \\
\text { ASYB Community } \\
\text { (Yogyakarta } \\
\text { Bersatu School } \\
\text { Alumni) and the } \\
\text { Santikara } \\
\text { Foundation }\end{array}$ & - & $\begin{array}{l}\text { Participate in } \\
\text { Gerkatin Seleman } \\
\text { activities }\end{array}$ & $\begin{array}{l}\text { Active in environmental } \\
\text { activities and church, } \\
\text { SRILI, PKRI }\end{array}$ & SRILI, and nature studio activities \\
\hline Business Name & $\begin{array}{l}\text { Porridge, salad, } \\
\text { pudding }\end{array}$ & $\begin{array}{l}\text { Wedang Bunga } \\
\text { Telang Drink }\end{array}$ & Mask business & - & Retno's snack box & Yogurt, eat smoked catfish \\
\hline
\end{tabular}


International Journal of Business and Applied Social Science (IJBASS)

E-ISSN: 2469-6501

VOL: 7, ISSUE: 11

November/2021

DOI: http://dx.doi.org/10.33642/ijbass.v7n11p3 cc) (i)

https://creativecommons.org/licenses/by/4.0/

\begin{tabular}{|c|c|c|c|c|c|c|}
\hline Business fields & $\begin{array}{l}\text { Food Clot } \\
\text { (Textiles) }\end{array}$ & Drink & Fabric masks (Textiles) & Service & Food & Food \\
\hline Address & - & Yogyakarta & - & Sleman & $\begin{array}{l}\text { Pakualaman, } \\
\text { Yogyakarta }\end{array}$ & Kasihan, Bantul \\
\hline $\begin{array}{l}\text { Month and } \\
\text { Year standing }\end{array}$ & 2017 & - & $\begin{array}{l}\text { When to ko } \\
\text { closed due to } \\
\text { the pandemic } \\
\text { finally sew } \\
\text { masks }\end{array}$ & - & 2010 & $\begin{array}{l}\text { Yogurt 2012); (Cooking Class } \\
\text { (2017/2018); Warung (2018) }\end{array}$ \\
\hline Start-up Capital & $\begin{array}{l}\text { Savings from selling } \\
\text { clothes used for food } \\
\text { business }\end{array}$ & - & Own savings & - & Own Savings & $\begin{array}{l}\text { Yogurt (own savings); Warung } \\
\text { (together with friends, then } \\
\text { takeover); cooking class (own) }\end{array}$ \\
\hline Number of employees & - & Just alone & - & - & $\begin{array}{l}2 \text { (only comes when } \\
\text { needed) }\end{array}$ & - \\
\hline $\begin{array}{l}\text { Domestic } \\
\text { Arrangement }\end{array}$ & $\begin{array}{l}\text { Working hard } \\
\text { to support her } \\
2 \text { children. } \\
\text { Doing work at home } \\
\text { alone, bringing } \\
\text { children } \\
\text { to work, accompany } \\
\text { in } \\
\text { making food for sale, } \\
\text { can only rest } 3 \text { hours a } \\
\text { day. }\end{array}$ & $\begin{array}{l}\text { It's not too much } \\
\text { trouble because } \\
\text { the kids are big } \\
\text { and can do } \\
\text { Their activities. }\end{array}$ & $\begin{array}{l}\text { Completed with } \\
\text { her husband so } \\
\text { He felt helped. } \\
\text { The children } \\
\text { Often play With } \\
\text { their cellphones } \\
\text { and are entrusted to lbu } \\
\text { Dwi's } \\
\text { parents. }\end{array}$ & $\begin{array}{l}\text { Doing by own } \\
\text { homework. Holiday } \\
\text { time is used to } \\
\text { participate in } \\
\text { activities in } \\
\text { Gerkatin. }\end{array}$ & $\begin{array}{l}\text { Helped by her } \\
\text { husband. Child } \\
\text { care is not a } \\
\text { hassle because } \\
\text { the child is big } \\
\text { and independent. }\end{array}$ & $\begin{array}{l}\text { The principle of spontaneity so that } \\
\text { all family me mbers have the } \\
\text { responsibility to do homework. }\end{array}$ \\
\hline Social Support received & $\begin{array}{l}\text { Get support from } \\
\text { friends. Her husband } \\
\text { and parents are not } \\
\text { supportive. }\end{array}$ & $\begin{array}{l}\text { Get support } \text { from } \\
\text { husband } \quad \text { and } \\
\text { children. }\end{array}$ & $\begin{array}{l}\text { Get support from } \\
\text { parents and husband. } \\
\text { Neither discriminate d } \\
\text { against as a disability. }\end{array}$ & $\begin{array}{l}\text { Get support } \\
\text { from deaf } \\
\text { community friends. } \\
\text { Her family is not } \\
\text { supportive and } \\
\text { often experiences } \\
\text { discrimination }\end{array}$ & $\begin{array}{l}\text { Get support from } \\
\text { husband, friends, and } \\
\text { parents. }\end{array}$ & $\begin{array}{l}\text { Get from and } \\
\text { support } \\
\text { husband } \\
\text { children. }\end{array}$ \\
\hline Role Conflict & $\begin{array}{l}\text { The multiple role } \\
\text { conflicts experienced } \\
\text { by the participants } \\
\text { were JPC/ Job-parent } \\
\text { conflict/ Work-parent } \\
\text { conflict and JHMC/ } \\
\text { Work- housewife } \\
\text { conflict. One of the } \\
\text { factors causing this } \\
\text { conflict is the } \\
\text { participant's status as } \\
\text { asingle parent. Did } \\
\text { everything myself and } \\
\text { felt the hassle. }\end{array}$ & $\begin{array}{l}\text { The multiple role } \\
\text { conflicts } \\
\text { experienced by the } \\
\text { participants were } \\
\text { JPC/ Job-parent } \\
\text { conflict/ Job- } \\
\text { parents. Her role in } \\
\text { doing homework, } \\
\text { she did himself } \\
\text { but she did not feel } \\
\text { the hassle.She has a } \\
\text { Telang flower drink } \\
\text { business and is } \\
\text { assisted by } 2 \\
\text { employees. } \\
\text { She became busier } \\
\text { because she took } \\
\text { many online classes } \\
\text { to grow her } \\
\text { business. }\end{array}$ & $\begin{array}{l}\text { The participant's } \\
\text { relationship with her } \\
\text { husband went well so } \\
\text { that the dual role she } \\
\text { felt did not create a } \\
\text { conflict. Her husband } \\
\text { helps with housework } \\
\text { so it doesn't feel like a } \\
\text { hassle. Her son is grown } \\
\text { and independent. She } \\
\text { owns acake business } \\
\text { which is assisted by } 2 \text { of } \\
\text { her employees. In } \\
\text { addition, she is active in } \\
\text { organization s and } \\
\text { becomes an } \\
\text { administrator in the } \\
\text { village. }\end{array}$ & $\begin{array}{l}\text { The dual role } \\
\text { conflict experienced } \\
\text { by the } \\
\text { participant did not } \\
\text { exist because he did } \\
\text { not have a partner } \\
\text { and children. }\end{array}$ & $\begin{array}{l}\text { The role conflict that } \\
\text { occurs is JPC/ Job-parent } \\
\text { conflict/ Job- parents. } \\
\text { Homework is not a hassle } \\
\text { because it is her husband } \\
\text { who does it. The task of } \\
\text { assisting children is left to } \\
\text { their parents. }\end{array}$ & $\begin{array}{l}\text { The multiple role conflicts } \\
\text { experienced by the participants were } \\
\text { JPC/ Job-parent conflict/ Job- } \\
\text { parents. } \\
\text { Her role in doing housework is carried } \\
\text { out with the principle of } \\
\text { Spontaneity where every family } \\
\text { member has the same responsibility. }\end{array}$ \\
\hline
\end{tabular}




\author{
E-ISSN: 2469-6501 \\ VOL: 7, ISSUE: 11 \\ November/2021 \\ DOI: http://dx.doi.org/10.33642/ijbass.v7n11p3 \\ (C) $\rightarrow$ \\ https://creativecommons.org/licenses/by/4.0/
}

\begin{tabular}{|c|c|c|c|c|c|c|}
\hline Performance of Women Entrepreneur $s$ & $\begin{array}{l}\text { Have a high } \\
\text { enthusiasm for work. } \\
\text { Including being } \\
\text { persistent and } \\
\text { unyielding is seen } \\
\text { when the pandemic } \\
\text { has an conomic } \\
\text { impact on most } \\
\text { people, he tries to } \\
\text { find activities that } \\
\text { make money other } \\
\text { than his job. } \\
\text { This was done by the } \\
\text { participant because of } \\
\text { the demands of the } \\
\text { situation that } \\
\text { positioned him as a } \\
\text { single parent with } 2 \\
\text { small children. } \\
\text { The existence of a } \\
\text { pandemic makes the } \\
\text { performance of } \\
\text { participants increase. }\end{array}$ & $\begin{array}{l}\text { Have a high } \\
\text { entrepreneurial l } \\
\text { spirit. } \\
\text { It can be seen from } \\
\text { his mindset to } \\
\text { always develop his } \\
\text { business and utilize } \\
\text { social media for } \\
\text { marketing. } \\
\text { Get into the flower } \\
\text { tea beverage } \\
\text { business because it } \\
\text { is quite profitable. } \\
\text { Viewed from the } \\
\text { organizational } \\
\text { aspect, participants } \\
\text { have } 2 \text { employees to } \\
\text { lead. } \\
\text { Always trying to } \\
\text { follow existing } \\
\text { trends, this proves } \\
\text { that the existence of a } \\
\text { pandemic actually } \\
\text { increases the } \\
\text { performance } \\
\text { of women } \\
\text { entrepreneurs. }\end{array}$ & $\begin{array}{l}\text { Have a high spirit to } \\
\text { continue to develop } \\
\text { their business. } \\
\text { Has } 11 \text { years of } \\
\text { experience in catering. } \\
\text { Have registered their } \\
\text { business with UMKM. } \\
\text { During the pandemic, } \\
\text { participants are to } \\
\text { improve the quality of } \\
\text { their merchandise } \\
\text {, packaging, marketing } \\
\text { and of Course the } \\
\text { Quality of taste. } \\
\text { The performance of } \\
\text { entrepreneur s due to the } \\
\text { pandemic is increasing, } \\
\text { this is due to declining } \\
\text { economic demands, so } \\
\text { they are trying to be able } \\
\text { to back up any } \\
\text { deficiencies through } \\
\text { improving product } \\
\text { quality. }\end{array}$ & $\begin{array}{l}\text { Often feels unsure } \\
\text { of his abilities. This } \\
\text { comes from the } \\
\text { environmental } \\
\text { treatment that did } \\
\text { not accept it since } \\
\text { childhood so that } \\
\text { the participants did } \\
\text { not seem confident } \\
\text { enough to showtheir } \\
\text { skills. At first, he } \\
\text { worked by getting } \\
\text { advice from his } \\
\text { close friends until } \\
\text { now he is still } \\
\text { working there. } \\
\text { He can make food but } \\
\text { he doesn't show it } \\
\text { because he feels that } \\
\text { what he is getting } \\
\text { now can meet his } \\
\text { daily needs. } \\
\text { The business } \\
\text { performance that } \\
\text { occurred to } \\
\text { participants after the } \\
\text { pandemic was not too } \\
\text { significant. }\end{array}$ & $\begin{array}{l}\text { Having a high work spirit, } \\
\text { is evidenced by the sewing } \\
\text { business that he has } \\
\text { established for a long time } \\
\text { The existence of this } \\
\text { pandemic had made her } \\
\text { stop sewing and help her } \\
\text { husband at the grocery } \\
\text { store, but with the sewing } \\
\text { skills, she had then started } \\
\text { to develop her sewing } \\
\text { business again, namely } \\
\text { sewing masks. } \\
\text { At the beginning of } \\
\text { sewing, he made a sizable } \\
\text { profit, but over time he felt } \\
\text { that he could not market } \\
\text { his products and was } \\
\text { unable to compete with } \\
\text { other products. }\end{array}$ & $\begin{array}{l}\text { Have a high enough enthusiasm for } \\
\text { entrepreneurship. } \\
\text { Previously he opened a cooking } \\
\text { class for foreign tourists while the } \\
\text { menu taught was a traditional } \\
\text { menu. However, due to the } \\
\text { economic downturn, some of his } \\
\text { businesses could not run, so he } \\
\text { focused more on running a yogurt } \\
\text { and coffee business. } \\
\text { In this effort, he always strives to } \\
\text { improve the quality and flavor } \\
\text { variants that exist in the two types } \\
\text { of drinks. } \\
\text { Not only that, participants always } \\
\text { think of strategies to run their } \\
\text { business, both in terms of product } \\
\text { procurement, BPOM permits, to } \\
\text { marketing. } \\
\text { The work performance experienced } \\
\text { by participants after the pandemic } \\
\text { has increased, this is due to the } \\
\text { many things that he must pay } \\
\text { attention to and keep running so } \\
\text { that the wheels of his family's } \\
\text { economy do not stop. }\end{array}$ \\
\hline
\end{tabular}

\section{Dual Role Conflict}

Job-Parent conflict (JPC), in its role as a woman who works and becomes a mother, only conflicts occur in female entrepreneurs who have children under 10 years of age. This is because children still need guidance and direction in concrete form from parents to instill their understanding, as in Piaget's theory (in IDAI, 2021) the development and growth period of children is divided into 4 stages, namely 18-24 months (sensorimotor period), 2-7 months. years (pre-operational period), 7-12 years (concrete operational period), and 12 years and above (formal operational period). Meanwhile, female entrepreneurs who have children above 12 years of age do not experience job parent conflict/JPC because at that age children can think abstractly.

In JMHC/work-housewife conflicts, namely the role of working women and the role of women as household managers vary, for single-parent women entrepreneurs, this will make it difficult because they cannot share tasks with their husbands, while for women entrepreneurs who have husbands and children will feel more helpful because they can share their duties so that homework is not only the mother's responsibility. Stereotypes about the roles of men and women in the household are starting to disappear in society so that the culture of doing housework becomes the wife's responsibility completely begins to fade. According to research conducted by Olson et al. (2011), couples who are both egalitarian (husband and wife) are happier than couples who are both traditional. This happens because the division of tasks is done based on personal interests and preferences rather than based on traditional demands. The adjustment of husband and wife makes the burden and task feel lighter because husband and wife support each other.

\section{Performance of Women Entrepreneurs}

Women entrepreneurs in this study continue to make improvements to their businesses, while the obstacles in running a business are capital. Under the statement of Hisrich et. al. (in Srihadiastuti, 2018) one of the most difficult problems in the process of establishing a new business is obtaining capital. Some women entrepreneurs have to use their savings for new venture capital. Some participants borrowed from state banks, but service workers (laundry workers) did not suffer losses due to this pandemic.

Besides that, other obstacles arise and affect the performance of the participants as women entrepreneurs, namely dual roles in the family, education level, lack of training, lack of confidence, lack of funds, legal and social formalities (Sunita, 2013). Somavia (in the ILO, 2013) states that work can determine the existence of humans, work is a way to survive and fulfill one's basic needs. In addition, work is also an activity carried out by individuals to gain recognition and self-identity. This is consistent with the results of a study in which women entrepreneurs say that their motivation to 


\author{
E-ISSN: 2469-6501 \\ VOL: 7, ISSUE: 11 \\ November/2021 \\ DOI: http://dx.doi.org/10.33642/ijbass.v7n11p3 \\ (c) (†) \\ https://creativecommons.org/licenses/by/4.0/
}

work is to be recognized in society and not be underestimated. Furthermore, women entrepreneurs in this study are women who have special needs, so they think that if they can be independent and have income, they will gain self-confidence and good self-acceptance in their environment.

Based on the results of the study, it was found that women entrepreneurs who have multiple roles increase their knowledge and skills by learning from experience and accessing information via the internet (such as watching videos on YouTube, taking online classes, etc.). What is done by women entrepreneurs is intended so that their business can develop so that the family's economy can be fulfilled. Each female entrepreneur in this study has diverse expertise, ranging from culinary, service, clothing, and home industries.

It can also be concluded that the performance of women entrepreneurs during the COVID-19 pandemic has experienced many improvements in terms of psychology consisting of perceptions of attitude, personality, learning, and motivation. This is due to the decline in the family's economy which reached $50 \%$ so that they continue to strive to develop skills, expand the product sales market, collect and access as much information as possible related to the field of business they are engaged in, seek opportunities and create strategies so that their products can survive in the community. Not only that with limitations as deaf, but they also have other motivations, namely to be accepted in society, recognized, and as selfesteem. Women entrepreneurs use technology to learn and improve their skills, such as taking online training and accessing information through YouTube. They also use social media to expand product marketing.

\section{Social Support}

The results show that social support is the main thing for women entrepreneurs, especially in carrying out dual role functions, namely as housewives and as women entrepreneurs. Especially for women entrepreneurs with disabilities (deaf) where they physically and psychologically need different attention. Women entrepreneurs with disabilities who often get bad treatment in society such as insults and ridicule as well as discrimination in the family have a fairly difficult acceptance of others. This expression is evidenced by the results of research that she only wants to be friends with her deaf friends, she is divorced from her husband, has no children, and is not related to her family. In contrast to female entrepreneurs who have disabilities but have families who always support and give appreciation. They are more mentally developed and easier to carry out their social roles. This is because the family is the closest party who coexists directly. Women with disabilities have the will to be well received and seen as humans in general, therefore they work and help the family economy to be financially independent so that their self-esteem is not seen as arbitrary.

The following is a description of the social support experienced by participants:
- For Ibu Dewi, the support from friends helps her business, starting from suggesting the type of business, helping to promote and sell the products of Ibu Dewi's cooking. Meanwhile, families such as parents and husbands do not provide support in any form. Ibu Dewi also gets emotional support from her friends, especially in telling stories about her family. Since childhood, Ibu Dewi has been trained to work hard, so that her mother only helps with housework and accompanies her child only when Ibu Dewi is sick, after that her mother will return with Ibu Dewi's stepfather.

- Her husband and children are very supportive of Ibu Nana to start this telang flower drink business. They already have their respective divisions. The husband runs the marketing department, Nana's mother is in production and the child is the media.

- Ibu Dwi gets social support from her parents and husband. Besides that, his friends too. Mrs. Dwi cooperates with other sellers; this is because if you do it yourself you will be confused (you can't do it online). The most important information media, what's trending. Ibu Dwi has never been discriminated against.

- Ibu Karsi gets social support from her deaf community friends, this is because both her parents have died while her 7 siblings are no longer communicating with each other. He also got a job, which he is currently pursuing from a friend's suggestion. While from his family he always gets discrimination for the shortcomings that exist in him. Many people like to make jokes so that she is only friends with friends from Gerkatin, Ibu Karsi hopes to be well received in her environment, appreciated, and given attention by her family.

- Ibu Retno gets support from her husband and friends in the cake business. Not only that, but parents are also supportive, this is evidenced by Ms. Retno's explanation that after graduating from high school, her parents suggested going to AKS Tarakanita (Cooking School).

- Ibu Endah in running her business gets support from her husband and children. Like her son volunteered to help Mother Endah to buy raw materials and others.

\section{Women Entrepreneurs with Disabilities}

Women entrepreneurs with disabilities who have sufficient social support from their environment prove that their existence is not a burden, they can play a role like humans in general with their physical conditions. Not only help their families financially, but they can also carry out social functions in their neighborhood such as being part of the management of community organizations, being village officials, participating in various communities, and participating in church activities. 


\author{
E-ISSN: 2469-6501 \\ VOL: 7, ISSUE: 11 \\ November/2021 \\ DOI: http://dx.doi.org/10.33642/ijbass.v7n11p3

Based on the results of the research, social support obtained from informants came from family and friends with disabilities. The forms of social support are classified into four according to Sheridan and Radmacher (2009), Sarafino (2011), Taylor (2012), and House (2004) namely, instrumental support, informational support, emotional support, and positive assessment. The instrumental support felt by women entrepreneurs with disabilities in this study was in the form of materials that they could access from online classes and social media, they also had the opportunity to run businesses and organize from their families.

In addition, his friends always provide opportunities for them to develop their businesses and get jobs. Informational support is obtained through the internet, friends, and family. Not only in the form of words but also in the form of actions, not only giving criticism but also providing suggestions and help in implementation. Emotional support is obtained in the form of spending time with family, sharing the burden of problems with friends, and sharing things that make women entrepreneurs feel comfortable. They do this because their family and friends are people who can accept their situation so that they put their trust in friends and family. A positive assessment in the form of acceptance of the surrounding environment for their physical condition, not mocking and ridiculing, not being discriminated against is an extraordinary award that they can feel like a person with a disability.

Social support makes women entrepreneurs become more confident and continue to try to develop their businesses, especially for those who get full support from family and friends, they will think ahead and be full of motivation to develop. As for disabled women entrepreneurs who receive social support from their friends and receive discrimination, they do not have enough motivation to think ahead or develop their businesses. What has been obtained at this time is something that only has to be carried out repeatedly without any other efforts to improve the economy.

Social support is a collection of social, emotional, cognitive, and behavioral processes that take place in a personal relationship where individuals receive assistance to make adaptive adjustments to the problems they face (Dalton, et al: 2001). Therefore, family support, especially husband and social environment is part of external social support. Social support received by someone is expected to ease the burden faced. Someone who gets social support will feel cared for, appreciated, and loved. Social support can provide physical and psychological comfort to individuals seen from how social support affects the incidence and effects of anxiety states.

\section{CONCLUSION}

\section{The Conclusion}

Based on the results of the study, it was concluded that the effect of multiple roles on the performance of women entrepreneurs was slightly felt in families with children aged over 12 years, while housewives who had children under 12 years had a considerable influence. The performance of women entrepreneurs during the Covid-19 pandemic has increased, this is due to declining economic conditions. While forms of social support that help women entrepreneurs to maintain their performance as entrepreneurs during the Covid19 pandemic are instrumental support, informational support, emotional support, and positive assessments obtained from family and friends. Social support is the main thing for women entrepreneurs to overcome dual role conflicts in their families, the social support they get berasal dari keluarga sehingga konflik peran ganda dalam keluarga tidak terjadi pada pengusaha wanita.

\section{Limitations}

This research is the initial research of a large umbrella of research with the topic of Analysis of the Effect of Multiple Role Conflicts on Performance Women Entrepreneurs During the COVID-19 Pandemic with Social Support as Moderating Variable. If the research can only produce a qualitative descriptive picture, then the dynamics of the influence and the relationship between variables are analyzed in the other part of the umbrella of this research.

\section{ACKNOWLEDGEMENT}

Thank you to LPPM UNIKA Atma Jaya for funding this research. Also to Regina widyani N (2018- 0101-0132) and Frenicha (NIM: 2016-070-298) as enumerators for the research data collection process.

\title{
REFERENCES
}

Adeline, Handayani, P., \& Irwanto. (2015). Hubungan konsep diri dan efikasi karir pada remaja akhir laki-laki penyandang disabilitas. Http://ijds.ub.ac.id.

Adioetomo, S.M., Mont, D., \& Irwanto. (2014). Persons with Disabilities in Indonesia: Empirical Facts and Implications for Social Protection Policies. TNP2K: Jakarta. http://www.tnp2k.go.id/images/uploads/downloads/Disabilities\%20report\%20Final\%20sept2014\%20(1)-1.pdf

Adkin, C. L., \& Premeaux, S. F. (2012). Spending time: The impact of hours worked on work-family conflict. Journal of Vocational Behavior, 80, 380-389.

Ahamad, I., \& Moudud-UI-Hug, S. (2013). Women entrepreneurship in Bangladesh challenges and prospects. International Journal of Innovative Research and Development, 2(7), 41-48. 


\author{
E-ISSN: 2469-6501 \\ VOL: 7, ISSUE: 11 \\ November/2021 \\ DOI: http://dx.doi.org/10.33642/ijbass.v7n11p3 \\ (c) (i) \\ https://creativecommons.org/licenses/by/4.0/
}

Alfons Olivia L, dkk. (2017). Peran Ibu Rumah Tangga Dalam Meningkatkan Status Sosial Keluarga Di Kelurahan Karombasan Selatan Kota Manado.

Campbell, Kathleen M. (1995). Competitive Frontiers: Woman Managers in A Global Economy”. Singapore. Asia Pacific Journal of Management, Vol.12, Iss.1; pg.115.

Conceptualization of Entrepreneurial Behavior. The Journal of Entrepreneurship, Vol. 9, No. 2; 135-154.

Garniger, Sunita. (2013). Women Social Entrepreneurs In India:Problems, Challenges And Strategies. Epra International Journal of Economic Business and Review. Vol.1 Issue 1.

Indriani, Devi, and Sugiasih, Inhastuti. (2016). Dukungan Sosial Dan Konflik Peran Ganda Terhadap Kesejahteraan Psikologis Karyawati PT. Sc Enterprises Semarang. Proyeksi, Vol.11 (1),46 - 54

Julianty, Evani; et all. (2016). Hubungan Antara Dukungan Sosial Suami Dengan Konflik Peran Ganda Pada Guru Wanita Di Kabupaten Halmahera Barat. Jurnal Psikologi Perseptual. Vol 1, No.1; 27- 39

Larasati, Yasmin. (2015). Hubungan Antara Dukungan Sosial Keluarga Dengan Konflik Peran Ganda Pada Wanita Bekerja. Naskah Publikasi Universitas Muhamadiyah Surakarta.

Lee, Jean S.K. and Choo Seow Ling. (2001). Work Family Conflict of Women Entrepeneurs in Singapore. Woman in Management Review, Vol.16 No.5 pp.204-221.

Kompasiana. (2018). Masihkah Pekerjaan Rumah Tangga Hanya Jadi Tanggung Jawab Perempuan Saja?. Diakses online https://www.kompasiana.com/sumiatun/5aa072edf1334426ee024632/international- women-s-day-perempuantetap-mendominasi

Nurdin, Yuniman Takwa. (2020). UMKM Perempuan Sumbang 9,1 Persen PDB. Pelaku Bisnis.com. Makarim Fadhli Rizal. (2021). Empat Tahapan Perkembangan Kognitif Si Kecil Dalam Teori Piaget. Diakses online

https://www.halodoc.com/artikel/4-tahapan-perkembangan-kognitif-si-kecil-dalam-teori-piaget

Oentari, H. W. (2019). Penerimaan diri pada penyandang disabilitas fisik karena kecelakaan. Diakses pada 19 November 2019 dari http://eprints.ums.ac.id/73826/13/NASKAHPUBLIKASI.pdf

Olson, D.H., DeFrain, J., Skogrand, L. (2011). Marriages and Families: Intimacy, Diversity and Strength. New York: Mc-Graw Hill, hal. 192-218

Olson, D.H., Sigg, A. O., Larson, P.J. (2008). The Couple Checkup: Find Your Relationship Strengths. Thomas Nelson, hal. 127-146

Prasetyo, Adi Yuli, et all. (2018). Analisis Pengaruh Konflik Keluarga-Pekerjaan, Hardiness, Self Efficacy Terhadap Stress Kerja Dengan Dukungan Sosial Sebagai Variabel Moderasinya (Studi Pada Guru Demak). Journal of Management, Vol.4, No.4.

Rachmaputri, Rosaria; Haryanti, Kristiana. (2015). Hubungan Dukungan Sosial Keluarga Dan Kepuasan Kerja Dengan WorkFamily Conflict Pada Anggota Ikatan Wanita Pengusaha Indonesia (Iwapi) JawaTengah. Psikodimensia, Vol. 14 / 2 2015

Ramadhani Ninin. (2016). Implikasi Peran Ganda Perempuan dalam Kehidupan Keluarga Dan Lingkungan Masyarakat. Cirebon. Sosietas Vol. 06 No 02.

Srihadiastuti, Rida. (2018). Analisis Faktor-Faktor Kendala Penyebab Kegagalan Mendirikan Usaha Baru Pada Para Lulusan Program Wirausaha Baru Jawa Barat Kelas Ide Bisnis. Universitas Telkom

Wongpay, Novensia. (2021). Pembagian peran dan tugas dalam rumah tangga: Seberapa penting?. Universitas Ciputra. Diakses online https://www.uc.ac.id/marriageandfamily/pembagian-peran-dan-tugas- dalam-rumah-tangga-seberapa-penting/

Yin, R. K. (2016). Qualitative research from start to finish. The Guilford Press. 